\title{
Body Composition, Psychological, Cardiovascular, and Physical Activity Factors Related with Academic School Performance
}

\author{
Laura Redondo-Flórez ${ }^{1}$, Domingo Jesus Ramos-Campo ${ }^{2}$ and Vicente Javier Clemente-Suárez ${ }^{1,3, *(\mathbb{D})}$ \\ 1 Faculty of Sports Sciences, Universidad Europea de Madrid, 28670 Madrid, Spain; \\ lauraredondo_1@hotmail.com \\ 2 Department of Education, Alcalá de Henares, University of Alcalá, 28801 Madrid, Spain; \\ domingojesus.ramos@uah.es \\ 3 Grupo de Investigación en Cultura, Educación y Sociedad, Universidad de la Costa, \\ Barranquilla 080002, Colombia \\ * Correspondence: vctxente@yahoo.es
}

Citation: Redondo-Flórez, L.;

Ramos-Campo, D.J.;

Clemente-Suárez, V.J. Body

Composition, Psychological,

Cardiovascular, and Physical Activity

Factors Related with Academic

School Performance. Sustainability

2021, 13, 8775. https://doi.org/

$10.3390 /$ su13168775

Academic Editors

Antonio Hernández-Mendo and

Gianpiero Greco

Received: 25 June 2021

Accepted: 1 August 2021

Published: 5 August 2021

Publisher's Note: MDPI stays neutral with regard to jurisdictional claims in published maps and institutional affiliations.

Copyright: (c) 2021 by the authors. Licensee MDPI, Basel, Switzerland. This article is an open access article distributed under the terms and conditions of the Creative Commons Attribution (CC BY) license (https:/ / creativecommons.org/licenses/by/ $4.0 /$ )

\begin{abstract}
The aim of the present study was to analyse body composition, anxiety, cardiovascular, and physical activity factors related with academic performance of school students as well as to analyse differences, by age, in these factors. We analysed in 266 primary school students' ( $8.81 \pm 1.62$ years, range: $5-13$ years) heart rate, anthropometric variables to calculate body mass index, physical activity performance, anxiety levels and academic results by the average of marks. Students were divided in two different groups, firstly by their lower or higher academic performance, and secondly by age. Results showed a negative correlation between academic performance and age, weight, body mass index and trait anxiety variables. Additionally, significant differences were found by age, presenting older students higher scores in body mass index and lower physical activity, trait anxiety, heart rate and academic performance values than younger students. Overweight and obesity may have a great impact in academic performance in children and we pointed out the necessity to establish programs related with healthy habits which include improvements in physical activity and nutrition behaviours with the objective to enhance children's health general status, psychological profile, cognitive and motor development, and academic performance.
\end{abstract}

Keywords: scholar students; obesity; anxiety; academic performance; stress

\section{Introduction}

Overweight and obesity are defined as an abnormal or excessive fat accumulation, which triggers in several pathologies, for which having high a body mass index (BMI) score is in an important risk factor [1]. Considering WHO estimations, which report that, since 1975, obesity has nearly tripled worldwide [1], it could be assumed that obesity has become a pandemic, which may have a great impact in childhood development as it has been described by previous literature. Psychologically, obese or overweight children showed major probability to suffer depression due to teasing and bullying [2-4] and a high prevalence of anxiety disorders in obese adolescents compared to non-obese ones [5,6]. Regarding to academic field, a review of several studies described an association between childhood obesity and poor academic performance [7,8]. Socioemotionally, obesity has been reported as "one of the most stigmatizing and least socially acceptable conditions in childhood" [9] as obese children have to deal with numerous difficulties such as bullying and stigma, discrimination and social marginalization and low self-esteem and lower self-reported quality of life, which in some cases may lead into suicidal ideation [3,10-13]. Physiologically, they presented a worse cardio metabolic profile due to the presence of metabolic syndrome, subclinical atherosclerosis and prematurely impaired vascular function [14-16].

Diverse childhood obesity causes have been widely described in literature. High sugary drinks consumption and increased portion sizes [17], decreased physical activity 
practices turn into sedentary behaviours (TV watching or playing in computer and other screen viewing) [18-20], and family factors such as living in a single parental household with an overweight parent [21], could be pointed out as important causes. Also, the recent COVID-19 pandemic had an important impact on children's weight, since it has been described how confinement has modified children's nutritional patterns, increasing their consumption of potato chips, sugary drinks and red meat [22]. As well, physical activity patterns have changed, especially in children who became less active and spent longer periods of time viewing different screens [23].

Assuming that obesity has become a pandemic, it is important to spotlight the effect that it has in children. It has been pointed out by previous literature how obesity may have a great impact in academic performance [24]. Thus, previous studies highlighted how elevated scores in BMI were related to worse academic performance [25], and predicted a poorer working memory and this, in turn, is associated with a lower level of academic performance [24]. Related to academic performance, it has been found that stress also could compromise learning, since previous researches showed how acute stress compromises synaptic efficacy and cortical plasticity [26], as well as leads to a reduction in blood flow in the prefrontal cortex, producing a decrease in oxygen and nutrients in the hippocampus, thereby triggering concentration difficulties, reducing memory ability potential [27] and decision making [28]. Related to stress, anxiety also may influence academic performance, being a stressor stimuli that pre-adolescents may not process properly, since their prefrontal cortex has not matured yet [29], implying a lack of development in the mechanisms regulating control of executive functions, in turn triggering a reduction in cognitive and memory skills [30]. Furthermore, high trait Anxiety, a scale which measures typical levels of anxiety, was negatively associated with academic performance in children [31]. In order to evaluate anxiety levels and autonomic modulation, previous researchers used heart rate (HR mean) as an easy tool to measure sympathetic modulation in students [32-34]. In line with this, previous research showed how school students showed sympathetic activation in hand with a high state anxiety [35]. Finally, physical activity has been highlighted as another significant factor which may modulate academic performance. Several authors proposed both physical and physiological benefits of regular physical practise in children, pointing out their improvement on different brain and cognitive skills, such as execution, decision, perception, concentration and memory [36-38]. The improvement of all these skills may be related with better academic performance.

The aim of the present study was to analyse body composition, anxiety, cardiovascular, and physical activity factors related to the academic performance of school students. As a secondary objective, we aimed to analyse age differences in academic performance, body composition, anxiety, cardiovascular and physical activity of school students. The initial hypothesis was that higher academic performance students would present a different body composition, anxiety, cardiovascular, and physical activity profile than lower academically performing students. The second hypothesis was that there would be differences in academic performance, body composition, anxiety, cardiovascular, and physical activity of school students i age.

\section{Materials and Methods}

\subsection{Participants}

Two hundred and sixty-six primary school students $(8.81 \pm 1.62$ years, from 5 to 13 years, $47 \%$ male and $53 \%$ female) were analysed. Children were recruited by convenience sampling from two schools in Madrid Community (Spain). They were divided in groups by age as follows: first primary stage (5-7 years) corresponding to 1st and 2nd school year, $n=69$; second primary stage (8-10 years) corresponding to 3 rd and 4 th school year, $n=154$; third primary stage (11-13 years) corresponding to 5 th and 6th year, $n=46$. The exclusion criteria were: (1) presenting with some type of pathology (diagnosed anxiety or depression, or attention-deficit disorder); (2) taking some kind of medication (anxiolytics, antidepressants, medication for attention-deficit disorder or any kind of medication which 
involves nervous system); (3) failure to provide informed consent by their legal guardians. To obtain the participants of the study, convenience sampling was used and the fathers, mothers, fathers' association, school management team and teachers were informed of the study objectives. The study information was explained personally, and an informed consent and study explanation inform were given to each mother, father or legal guardian of the students. Subsequently, the students who gave the evaluators the consent form signed by their father, mother or legal guardian were analysed. $46 \%$ of the school students agreed to carry out the study. All participants, parental figures and their professors were informed about the experimental procedures, indicating the right to withdraw from the study at any time, and were required to compelte an informed consent form prior to the start of theresearch, following the Helsinki Declaration (as revised in Brazil, 2013). The procedure was approved by the European University of Madrid Ethical Committee (CIPI/18/074).

\subsection{Procedure}

To reach the main objective of the present research, participants were divided in two groups of equal size according to their academic performance (percentile 50). The lower academic performance group included scores between 3.80 and 6.90 of 10; and higher academic performance group included scores between 7.00 and 9.44 of 10. Regarding the second objective, students were divided in three age groups (1st, 2nd and 3rd stage, or $5-7$ years, $8-10$ years and 11-13 years, respectively) in order to analyse differences in the study variables by age.

\subsection{Measures}

The heart rate was measured with a Polar V800 heart rate monitor (Polar, Kempele, Finland). Evaluations were made on April 2019 between 09:00 AM and 10:30 AM with the student sited in a quiet and calm room, while a professor supervised them.

Body mass was measured using a SECA scale model 714 (Seca, Hamburg, Germany) with precision of $100 \mathrm{~g}$ (range $0.1-130 \mathrm{Kg}$ ), located on a flat and smooth surface and calibrated at zero. Subjects were barefoot and with minimal clothes.

Height was measured with a height rod, incorporated in the scale SECA model 714, with precision of $0.1 \mathrm{~mm}$.

Body Mass Index (BMI) was calculated using the classic formula: weight $(\mathrm{kg}) /$ height $(\mathrm{m})^{2}$.

Physical activity was analysed with a validated self-report questionnaire for children [39], the PAQ-C. This questionnaire is composed of nine questions. The first one provides contextual cues by checking 22 common free-time and physical activities, as well as two "other" fill-in choices. The other eight questions are organised using time-of-day or day-of-the-week structure. All of them score using a 1-5 scale. The summary score is the average of the sum of the nine items.

Anxiety was measured by the State-Trait Anxiety Inventory for Children and Adolescents (STAIC) [40]. The questionnaire is composed of two 20-item scales to measure state anxiety and trait anxiety.

The academic performance was analysed by the average of marks in all subjects conducted by the students.

\subsection{Data Analysis}

Statistical analysis was carried out using Statistical Package for the Social Sciences (SPSS) version 24.0 for Windows (IBM Spain). Descriptive statistics (mean and standard deviation) were analysed for each variable. A Kolmogorov-Smirnov test was used to test the normality of the sample. Homoscedasticity was checked by Levene's test. All the variables passed the normality and homoscendasticity tests. Then, an independent $\mathrm{T}$ test was conducted between the high and low school-performance groups and a multivariate analysis of variance (MANOVA), with age as a fixed factor, was conducted to test differences in study variables by age. In addition, a bivariate correlational analysis by the Pearson 
test was conducted. The effect size (ES) was tested by partial square eta $\left(\eta^{2}\right)$. The level of significance for all the comparisons was set at $p \leq 0.05$

\section{Results}

Results are presented as average \pm standard deviation. The lower academic performance group presented a significantly lower scores than the higher group $(5.99 \pm 0.72 \mathrm{vs}$. $7.96 \pm 0.59$ ). Table 1 summarised differences in the analysed variables between higher academic performance group and lower academic performance group. We found significant differences in BMI values $(p=0.013)$. No significant differences were found in age, weight, height, heart rate, state anxiety or trait anxiety variables. In the correlational analysis we found a negative significant correlation between academic performance and age ( $\mathrm{r}:-0.154$; $p: 0.012)$, weight ( $\mathrm{r}:-0.159 ; p$ : 0.012), BMI ( $\mathrm{r}:-0.150, p: 0.019)$ and trait anxiety $(\mathrm{r}:-0.122$; $p: 0.047)$.

Table 1. Body composition, heart rate, physical activity and anxiety variables in lower academic performance group and higher academic performance group.

\begin{tabular}{|c|c|c|c|c|c|c|c|}
\hline \multicolumn{8}{|c|}{ 95\% Confidence } \\
\hline Variable & $\begin{array}{c}\text { Higher } \\
\text { Academic } \\
\text { Performance } \\
\text { Group }\end{array}$ & $\begin{array}{c}\text { Lower } \\
\text { Academic } \\
\text { Performance } \\
\text { Group }\end{array}$ & $\mathbf{t}$ & $p$-Value & Lower & Upper & $\eta^{2}$ \\
\hline $\begin{array}{c}\text { Age } \\
\text { (years) }\end{array}$ & $8.67 \pm 1.61$ & $8.98 \pm 1.62$ & 1.552 & 0.122 & -0.083 & 0.70 & 0.013 \\
\hline $\begin{array}{l}\text { Height } \\
(\mathrm{cm})\end{array}$ & $138.17 \pm 11.78$ & $138.18 \pm 12.30$ & 0.001 & 0.999 & -3.03 & 3.03 & 0.00 \\
\hline $\begin{array}{l}\text { Weight } \\
(\mathrm{kg})\end{array}$ & $35.14 \pm 9.52$ & $37.51 \pm 11.34$ & 1.795 & 0.074 & -0.23 & 4.98 & 0.011 \\
\hline $\begin{array}{l}\text { Body Mass Index } \\
\qquad\left(\mathrm{kg} / \mathrm{m}^{2}\right)\end{array}$ & $18.20 \pm 3.36$ & $19.32 \pm 3.68$ & 2.496 & 0.013 & 0.236 & 2.01 & 0.024 \\
\hline $\begin{array}{l}\text { Heart Rate } \\
\text { (bpm) }\end{array}$ & $99.01 \pm 43.48$ & $98.02 \pm 68.69$ & -0.138 & 0.891 & -15.024 & 13.06 & 0.016 \\
\hline Physical Activity & $1.71 \pm 0.54$ & $1.62 \pm 0.62$ & 1.287 & 0.199 & -0.493 & 0.235 & 0.008 \\
\hline State Anxiety & $28.75 \pm 3.51$ & $28.08 \pm 4.60$ & -1.332 & 0.184 & -1.658 & 0.320 & 0.004 \\
\hline Trait Anxiety & $25.12 \pm 4.47$ & $25.61 \pm 5.12$ & 0.828 & 0.408 & -0.673 & 1.651 & 0.006 \\
\hline
\end{tabular}

The MANOVA report significant differences between the three groups of comparison (Wilks lambda $=0.156 ; \mathrm{F}=39.52 ; p=0.000$ ). Significant differences were found in BMI $(p=0.005)$, physical activity $(p=0.021)$, trait anxiety $(p=0.036)$, heart rate $(p=0.000)$ and academic performance $(p=0.009)$ between groups in their 1st, 2nd and 3rd stages. Thus, BMI values significantly increased as age increased, whereas physical activity, trait anxiety, heart rate and academic performance significantly decreased as age increased (Table 2).

Table 2. Body composition. heart rate. physical activity and anxiety variables in different stages divided by age.

\begin{tabular}{cccccc}
\hline Variable & 1st Stage & 2nd Stage & 3rd Stage & $\boldsymbol{F}$ & $p$-Value \\
\hline $\begin{array}{c}\text { Age } \\
\text { (years) }\end{array}$ & $6.72 \pm 0.45$ & $9.10 \pm 0.77$ & $11.17 \pm 0.48$ & 527.635 & 0.000 \\
$\begin{array}{c}\text { Height } \\
(\mathrm{cm})\end{array}$ & $124.22 \pm 7.68$ & $139.58 \pm 9.49$ & $149.19 \pm 8.57$ & 96.801 & 0.000 \\
$\begin{array}{c}\text { Weight } \\
(\mathrm{kg})\end{array}$ & $27.14 \pm 6.18$ & $36.99 \pm 9.13$ & $44.57 \pm 11.02$ & 45.589 & 0.000 \\
$\begin{array}{c}\text { Body Mass Index } \\
\left(\mathrm{kg} / \mathrm{m}^{2}\right)\end{array}$ & $17.51 \pm 3.16$ & $18.86 \pm 3.56$ & $19.82 \pm 3.67$ & 5.322 & 0.005 \\
\hline
\end{tabular}


Table 2. Cont.

\begin{tabular}{|c|c|c|c|c|c|}
\hline Variable & 1st Stage & 2nd Stage & 3rd Stage & $F$ & $p$-Value \\
\hline $\begin{array}{l}\text { Heart Rate } \\
\text { (bpm) }\end{array}$ & $98.41 \pm 10.78$ & $94.58 \pm 8.73$ & $86.26 \pm 6.52$ & 24.108 & 0.000 \\
\hline $\begin{array}{l}\text { Physical } \\
\text { Activity }\end{array}$ & $1.90 \pm 0.42$ & $1.70 \pm 0.55$ & $1.59 \pm 0.68$ & 3.930 & 0.021 \\
\hline $\begin{array}{c}\text { State } \\
\text { Anxiety }\end{array}$ & $29.56 \pm 3.15$ & $28.39 \pm 4.22$ & $28.19 \pm 4.27$ & 1.833 & 0.162 \\
\hline $\begin{array}{c}\text { Trait } \\
\text { Anxiety }\end{array}$ & $26.06 \pm 5.58$ & $25.74 \pm 4.44$ & $23.91 \pm 3.53$ & 3.368 & 0.036 \\
\hline $\begin{array}{c}\text { Academic } \\
\text { Performance }\end{array}$ & $7.34 \pm 0.92$ & $6.94 \pm 1.18$ & $6.62 \pm 1.28$ & 4.767 & 0.009 \\
\hline
\end{tabular}

\section{Discussion}

The aim of the present research was to analyse body composition, anxiety, cardiovascular and physical activity differences in school students as they related to their academic performance. The initial hypothesis was partially confirmed, since students of higher academic performance presented a lower BMI than lower academically performing students. Our hypothesis for the secondary objective was confirmed, since students presented lower values for academic performance, anxiety, cardiovascular and physical activity as age increased, whereas BMI scores increased with age.

According to growth charts stablished by the WHO, children in the present study showed BMI values consistent with overweight or obesity, since they showed a percentiles upper than 85 , percentile 5 to $85 \%$ considered as normal weight [41]. Significant differences were found in BMIs between the higher academic performance and lower academic performance groups, as well as a significant negative correlation between academic performance and BMI, in consonance with previous studies $[33,42]$. These findings were also supported by previous studies, which related lower working memory in students with higher BMI scores, which is also associated with a lower academic performance [24], as well as lower math and reading test scores [43,44], inferior arts and science test scores [44], lower efficiency in conflict resolution and poorer inhibitory control [45]. These differences in learning could be related to the activity of brain neurotrophic factor (BDNF), which plays an important role in synaptic plasticity in the hippocampus [46,47], affects emotional decision-making performance [48], modulates the establishment of neuronal circuits and is implicated in long-term memory [46], decreased levels of which have been highlighted in obese children and adolescents $[49,50]$ as implying worse academic performance. Nevertheless, recent studies suggested that the association between obesity and low academic achievement is not well stablished, and more research is needed [51,52]. Additionally, significant differences were found in BMI with respect to the student's grade; students in higher academic stages showed larger BMI values, which might be explained by the significantly less weekly physical activity shown by these students and the normal growth process associated with those ages [35].

No significant differences were found in anxiety levels between higher and lower academic performance groups. By contrary, significant trait anxiety differences were found with respect to student's age. Thus, younger students showed higher trait anxiety values than older ones, consistent with recent research [53]. The trait scale provides indications of a long-lasting tendency to experience anxiety, which may predict an anxiety tendency in adulthood, since when anxiety takes place in childhood it also tends to be widespread in adulthood, and is also commonly related with several psychopathologies [54]. Additionally, a negative correlation between academic performance and trait anxiety was found in the present study, in accordance with previous research [31,55], which pointed out the influence that anxiety may have on academic performance, since a negative relation has been found between trait anxiety and test performance in students with low working memory capacity, as well as a positive relation between trait anxiety and test performance in those with 
high working memory capacity. This result highlights a common health problem around the world, with an increasing number of anxiety patients, especially in early ages, that highlights the necessity of efficient interventions $[56,57]$. Due to the great impact that anxiety has on children and their academic performance, previous authors proposed the use of a biofeedback relaxation training program, including deep breathing, positive visualization and muscle relaxation, which had positive effects in students, decreasing anxiety levels and increasing academic performance [58].

Regarding physical activity, no significant differences were found between the higher academic performance group and lower academic performance group. Furthermore, students showed a low physical activity practice, contrary to the recommendations in children and adolescents from health promoting institutions, which proposed at least $60 \mathrm{~min}$ per day of moderate to vigorous intensity physical activities [59]. Moreover, the present research showed how physical activity decreased with academic performance. These results were consistent with previous studies, in which it was found that children with higher fitness levels showed greater semantic processing [60], higher ability to access a richer lexicalsemantic system, which allows them to detect syntactic mistakes faster. It also aids their having better language and reading skills [61], superior ability extracting meaning and relation in mathematics problems [62] and greater ability facilitating attentional processing when facing more difficult activities by defeating nonessential neural operations [63]. Several mechanisms explaining this association have been widely described in the literature. It has been pointed out that cardiorespiratory fitness enhances brain structure and function by affecting neural substrates, improving concentration and memory processes [64]. Additionally, previous studies proposed cardiorespiratory fitness's capability to increase neuronal density synapsis [64] and increase the vasculature in cortex [65]. Furthermore, due to physical training process and cultivating vigilance, students might be better oriented to achieve success [66]. It was also described how cardiorespiratory fitness improved the synthesis of BDNF, also associated with better academic performance, as previously described $[67,68]$. Relating to HR, no significant differences were found between the higher academic performance group and the lower academic performance group. Nevertheless, it was found that HR significantly decreased as age increased, in consonance with normative values [69], as well as in accordance with previous studies [33,70], in which heart rates around 100 and 105 beats per minute (bpm) were found in children between 4 and 6 years, $100 \mathrm{bpm}$ in children between 6 and 8 years and 86 and $94 \mathrm{bpm}$ in children between 8 and 12 years, consistent with a normal maturation of the autonomic nervous system [71].

\subsection{Practical Applications}

Physical activity has been pointed out as an important key factor in children and adolescent's development, since it improves brain neurotrophic factors, basic general development in children and the advancement of their cognitive and neuromotor capabilities, as, in early stages of life, motor and cognitive structures are still growing. Consequently, it could have a positive effect in their academic performance. With respect to the obesity pandemic that is gravely affecting children and adolescents, it is necessary to implement programs that involve parental and community interventions, as well as interventions from children's parental figures, relating to healthy habits, which include enhancements in physical activity and nutrition patterns, with aim to improve their general health status, as well as their cognitive functions, academic performance, psychological profiles and their motor development.

\subsection{Limitation of the Study and Future Research Lines}

The main limitation of the present research was the lack of biological measures of stress hormones and neurotrophin family proteins (cortisol, alpha-amylase, BDNF, etc.) due to resource availability. Future research may address these issues, as it would improve the complete knowledge of stress on this community. Additionally, another limitation of the study was that we did not consider the entire physical activity undertaken by students, 
inside and outside school. Furthermore, another limitation of the study was that we did not consider gender and social class of the children, nor their parents' education level, which could have an important effect in values toward BMI, physical activity and academic performance. Additionally, we considered the average grade to evaluate academic performance, which could be also considered as a limitation of the study. As certain subjects could be confounding factors, since course difficulty depending increase with the age of participants, it may be more appropriate the use a literary or arithmetic task as a better fit, with the aim of evaluating academic performance, than students' grades. Moreover, we did not consider stigma, bullying or absenteeism, which also could have a great impact in academic performance and general health states of children. Future studies should consider these issues. Given the proportion of the sample, 47\% men and 53\% women, here we have not considered gender in the study; it may have been very interesting to see if the differences and correlations found are maintained across gender.

Future research lines should consider the use of effective anxiety, nutritional and physical activity interventions, which may enhance general health status as well as academic performance in children. In addition, considering the gender distribution in the sample was very equitable, it would be interesting to see if the differences and correlations found are maintained across gender; future research lines should consider this issue. Furthermore, it would be interesting to analyse the effect of the COVID-19 pandemic on the academic performance of students, since it was a significant new stressor that elicited disruptive behaviours and feelings [72] and the effect on students is poorly understood. In line with this, the use of bioimpedanciometer would give more information regarding the influence of different anthropometric variables, and is a non-invasive and reliable instrument to apply in this population [73].

\section{Conclusions}

We found a negative correlation between academic performance and age, weight, BMI and anxiety values. In addition, older students presented higher BMI values, as well as lower academic performance, anxiety, cardiovascular and physical activity scores than younger students. Future studies may address the importance of efficient strategies involving anxiety, nutritional and physical activity issues which could improve general health status and academic performance in this population.

Author Contributions: Conceptualization, V.J.C.-S.; methodology, V.J.C.-S. and L.R.-F.; investigation, V.J.C.-S. and L.R.-F.; writing-original draft preparation, all authors; writing-review and editing, all authors; supervision, V.J.C.-S. All authors have read and agreed to the published version of the manuscript.

Funding: This research received no external funding.

Institutional Review Board Statement: The study was conducted according to the guidelines of the Declaration of Helsinki, and approved by the Institutional Ethics Committee (CIPI/18/074).

Informed Consent Statement: Informed consent was obtained from all subjects involved in the study.

Data Availability Statement: All the data are in the manuscript.

Conflicts of Interest: The authors declare no conflict of interest. The funders had no role in the design of the study; in the collection, analyses, or interpretation of data; in the writing of the manuscript, or in the decision to publish the results.

\section{References}

1. WHO. Obesidad y Sobrepeso. Available online: https://www.who.int/es/news-room/fact-sheets/detail/obesity-andoverweight (accessed on 14 February 2021).

2. Luppino, F.S.; de Wit, L.M.; Bouvy, P.F.; Stijnen, T.; Cuijpers, P.; Penninx, B.W.J.; Zitman, F.G. Overweight, Obesity and Depression. Arch. Gen. Psychiatry 2010, 67, 220-229. [CrossRef] [PubMed]

3. Janssen, I.; Craig, W.M.; Boyce, W.F.; Pickett, W. Associations Between Overweight and Obesity with Bullying Behaviors in School-Aged Children. Pediatrics 2004, 113, 1187-1194. [CrossRef] [PubMed] 
4. $\quad$ Rankin, J.; Matthews, L.; Cobley, S.; Han, A.; Sanders, R.; Wiltshire, H.D.; Baker, J.S. Psychological Consequences of Childhood Obesity: Psychiatric Comorbidity and Prevention. Adolesc. Health. Med. Ther. 2016, 7, 125-146. [CrossRef] [PubMed]

5. Wang, S.; Sun, Q.; Zhai, L.; Bai, Y.; Wei, W.; Jia, L. The Prevalence of Depression and Anxiety Symptoms among Overweight/Obese and Non-Overweight/Non-Obese Children/Adolescents in China: A Systematic Review and Meta-Analysis. Int. J. Environ. Res. Public Health. 2019, 16, 340. [CrossRef]

6. Topçu, S.; Orhon, F.S.; Tayfun, M.; Uçaktürk, S.A.; Demirel, F. Anxiety, Depression and Self-Esteem Levels in Obese Children: A Case-Control Study. J. Pediatr. Endocrinol. Metab. 2016, 29, 357-361. [CrossRef]

7. Taras, H.; Potts-Datema, W. Obesity and Student Performance at School. J. Sch. Health. 2005, 75, 291-295. [CrossRef]

8. Liang, J.; Matheson, B.E.; Kaye, W.H.; Boutelle, K.N. Neurocognitive Correlates of Obesity and Obesity-Related Behaviors in Children and Adolescents. Int. J. Obes. 2014, 38, 494-506. [CrossRef]

9. Schwimmer, J.B.; Burwinkle, T.M.; Varni, J.W. Health-Related Quality of Life of Severely Obese Children and Adolescents. Am. Med. Assoc. 2003, 289, 1813-1819. [CrossRef] [PubMed]

10. Halfon, N.; Larson, K.; Slusser, W. Associations between Obesity and Comorbid Mental Health, Developmental, and Physical Health Conditions in a Nationally Representative Sample of Us Children Aged 10 to 17. Acad. Pediatr. 2013, 13, 6-13. [CrossRef]

11. Morrison, K.M.; Shin, S.; Tarnopolsky, M.; Taylor, V.H. Association of Depression \& Health Related Quality of Life with Body Composition in Children and Youth with Obesity. J. Affect. Disord. 2015, 172, 18-23. [CrossRef]

12. Beck, A.R. Psychosocial Aspects of Obesity. NASN Sch. Nurse 2016, 1, 23-27. [CrossRef]

13. Ackard, D.M.; Neumark-sztainer, D.; Story, M.; Perry, C. Overeating Among Adolescents: Prevalence and Associations With Weight-Related Characteristics and Psychological Health. Pediatrics 2003, 111, 15-17. [CrossRef]

14. Calcaterra, V.; Klersy, C.; Muratori, T.; Telli, S.; Caramagna, C.; Scaglia, F.; Cisternino, M.; Larizza, D. Prevalence of Metabolic Syndrome (MS) in Children and Adolescents with Varying Degrees of Obesity. Clin. Endocrinol. 2008, 68, 868-872. [CrossRef]

15. Schlager, O.; Willfort-Ehringer, A.; Hammer, A.; Steiner, S.; Fritsch, M.; Giurgea, A.; Margeta, C.; Lilaj, I.; Zehetmayer, S.; Widhalm, K.; et al. Microvascular Function Is Impaired in Children with Morbid Obesity. Vasc. Med. 2011, 16, 97-102. [CrossRef]

16. Ice, C.L.; Murphy, E.; Cottrell, L.; Neal, W.A. Morbidly Obese Diagnosis as an Indicator of Cardiovascular Disease Risk in Children: Results from the CARDIAC Project. Int. J. Pediatr. Obes. 2011, 6, 113-119. [CrossRef] [PubMed]

17. Anderson, P.M.; Butcher, K.F. Childhood Obesity: Trends and Potential Causes. Futur. Child. 2006, 16, 19-45. [CrossRef]

18. Ren, H.; Zhou, Z.; Liu, W.K.; Wang, X.; Yin, Z. Excessive Homework, Inadequate Sleep, Physical Inactivity and Screen Viewing Time Are Major Contributors to High Paediatric Obesity. Acta Paediatr. Int. J. Paediatr. 2017, 106, 120-127. [CrossRef] [PubMed]

19. Prentice-dunn, H.; Prentice-dunn, S. Physical Activity, Sedentary Behavior and Childhood Obesity: A Review of Cross-Sectional Studies. Psychol. Health Med. 2012, 17, 255-273. [CrossRef] [PubMed]

20. Maher, C.; Olds, T.S.; Eisenmann, J.C.; Dollman, J. Screen Time Is More Strongly Associated than Physical Activity with Overweight and Obesity in 9- to 16-Year-Old Australians. Acta Paediatr. 2012, 101, 1170-1174. [CrossRef]

21. Moens, E.; Braet, C.; Bosmans, G.; Rosseel, Y. Unfavourable Family Characteristics and Their Associations with Childhood Obesity: A Cross-Sectional Study. Eur. Eat. Disord. Rev. 2009, 17, 315-323. [CrossRef]

22. Clemente-Suárez, V.J.; Ramos-Campo, D.J.; Mielgo-Ayuso, J.; Dalamitros, A.A.; Nikolaidis, P.A.; Hormeño-Holgado, A.; TorneroAguilera, J.F. Nutrition in the Actual Covid-19 Pandemic. A Narrative Review. Nutrients 2021, 13, 1924. [CrossRef]

23. Kola, L. Global mental health and COVID-19. Lancet Psychiatry 2020, 7, 655-657. [CrossRef]

24. Wu, N.; Chen, Y.; Yang, J.; Li, F. Childhood Obesity and Academic Performance: The Role of Working Memory. Front. Psychol. 2017, 8, 1-7. [CrossRef]

25. Rajagopal, M.; Briggs, A.; Omar, H. Association Between School Performance and Body Mass Index. Int. J. Child Adolesc. Health 2017, 10, 59.

26. Concerto, C.; Patel, D.; Infortuna, C.; Chusid, E.; Muscatello, R.; Bruno, A.; Zoccali, R.; Aguglia, E.; Muscatello, M.R.; Bruno, A.; et al. Academic Stress Disrupts Cortical Plasticity in Graduate Students. Stress 2017. [CrossRef]

27. Delgado-Moreno, R.; Robles-Pérez, J.J.; Clemente-Suárez, V.J. Combat Stress Decreases Memory of Warfighters in Action. J. Med. Syst. 2017, 1-7. [CrossRef] [PubMed]

28. Morgan, C.A.; Doran, A.; Steffian, G.; Hazlett, G.; Southwick, S.M. Stress-Induced Deficits in Working Memory and VisuoConstructive Abilities in Special Operations Soldiers. Biol. Psychiatry 2006. [CrossRef]

29. Gogtay, N.; Giedd, J.N.; Lusk, L.; Hayashi, K.M.; Greenstein, D.; Vaituzis, A.C.; Nugent, T.F.; Herman, D.H.; Clasen, L.S.; Toga, A.W.; et al. Dynamic Mapping of Human Cortical Development during Childhood through Early Adulthood. Proc. Natl. Acad. Sci. USA 2004, 101, 8174-8179. [CrossRef] [PubMed]

30. Semrud-Clikeman, M.; Ellison, P.A.T. Child Neuropsychology: Assessment and Interventions for Neurodevelopmental Disorders, 2nd ed.; Springer: Berlin, Germany, 2009.

31. Owens, M.; Stevenson, J.; Norgate, R.; Hadwin, J.A. Processing Efficiency Theory in Children: Working Memory as a Mediator between Trait Anxiety and Academic Performance. Anxiety Stress Coping 2008, 21, 417-430. [CrossRef] [PubMed]

32. Redondo Flórez, L.; Tornero-Aguilera, J.F.; Clemente-Suárez, V.J. Could Academic Experience Modulate Psychophysiological Stress Response of Biomedical Sciences Students in Laboratory? Physiol. Behav. 2020, 113017. [CrossRef]

33. Mendoza-Castejón, D.; Clemente-Suárez, V.J. Autonomic Profile, Physical Activity, Body Mass Index and Academic Performance of School Students. Sustainability 2020, 12, 6718. [CrossRef] 
34. Beltrán-Velasco, A.I.; Mendoza-Castejón, D.; Fuentes-García, J.P.; Clemente-Suárez, V.J. Behavioural, psychological, and physiological stress markers and academic performance in immigrant and non-immigrant preschool and school students. Physiol. Behav. 2020, 225, 113081. [CrossRef] [PubMed]

35. Mendoza-Castejón, D.; Clemente-Suárez, V.J. Psychophysiological Stress Markers and Behavioural Differences between Rural and City Primary School Students. Int. J. Environ. Res. Public Health 2020, 17, 3157. [CrossRef]

36. Loprinzi, P.D.; Cardinal, B.J.; Loprinzi, K.L.; Lee, H. Benefits and Environmental Determinants of Physical Activity in Children and Adolescents. Obes. Facts 2012, 597-610. [CrossRef]

37. Donnelly, J.E.; Hillman, C.H.; Castelli, D.; Etnier, J.L.; Lee, S.; Tomporowski, P.; Lambourne, K.; Szabo-Reed, A.N. Physical Activity, Fitness, Cognitive Function, and Academic Achievement in Children: A Systematic Review. Med. Sci. Sports Exerc. 2016, 48, 1197-1222. [CrossRef]

38. Gomes da Silva, S.; Arida, R.M. Physical Activity and Brain Development. Expert Rev. Neurother. 2015, 15, 1041-1051. [CrossRef]

39. Janz, K.F.; Lutuchy, E.M.; Wenthe, P.; Levy, S.M. Measuring Activity in Children and Adolescents Using Self-Report: PAQ-C and PAQ-A. Med. Sci. Sports Exerc. 2008, 40, 767-772. [CrossRef]

40. Rabian, B.; Embry, L.; Macintyre, D.; Rabian, B.; Embry, L.; Macintyre, D. Behavioral Validation of the Childhood Anxiety Sensitivity Index in Children Behavioral Validation of the Childhood Anxiety Sensitivity Index in Children. J. Clin. Child Psychol. 1999, 28, 105-112. [CrossRef] [PubMed]

41. WHO. Growth Reference Data for 5-19 Years. Available online: https://www.who.int/tools/growth-reference-data-for-5to19years / indicators / bmi-for-age (accessed on 25 June 2021).

42. He, J.; Chen, X.; Fan, X.; Cai, Z.; Huang, F. Is There a Relationship between Body Mass Index and Academic Achievement? A Meta-Analysis. Public Health 2019, 167, 111-124. [CrossRef]

43. Judge, S.; Jahns, L. Association of Overweight With Academic Performance and Social and Behavioral Problems: An Update From the Early Childhood Longitudinal Study. J. Sch. Health 2007, 77, 672-678. [CrossRef] [PubMed]

44. Cottrell, L.A.; Northrup, K.; Wittberg, R.; Lesley, A.; Northrup, K. The Extended Relationship between Child Cardiovascular Risks and Academic Performance Measures. Obesity 2007, 15, 3170-3177. [CrossRef]

45. Kamijo, K.; Pontifex, M.B.; Khan, N.A.; Raine, L.B.; Scudder, M.R.; Drollette, E.S.; Evans, E.M.; Castelli, D.M.; Hillman, C.H. The Association of Childhood Obesity to Neuroelectric Indices of Inhibition. Psychophysiology 2012, 49, 1361-1371. [CrossRef]

46. Greenberg, M.E.; Xu, B.; Lu, B.; Hempstead, B.L. New Insights in the Biology of BDNF Synthesis and Release: Implications in CNS Function. J. Neurosci. 2009, 29, 12764-12767. [CrossRef]

47. Bramham, C.R.; Messaoudi, E. BDNF Function in Adult Synaptic Plasticity: The Synaptic Consolidation Hypothesis. Prog. Neurobiol. 2005, 76, 99-125. [CrossRef]

48. Kang, J.I.; Namkoong, K.; Ha, R.Y.; Jhung, K.; Kim, Y.T.; Kim, S.J. Influence of BDNF and COMT Polymorphisms on Emotional Decision Making. Neuropharmacology 2010, 58, 1109-1113. [CrossRef]

49. Araki, S.; Yamamoto, Y.; Dobashi, K.; Asayama, K.; Kusuhara, K. Decreased Plasma Levels of Brain-Derived Neurotrophic Factor and Its Relationship with Obesity and Birth Weight in Obese Japanese Children. Obes. Res. Clin. Pract. 2014, 8, e63-e69. [CrossRef]

50. El-Gharbawy, A.H.; Adler-Wailes, D.C.; Mirch, M.C.; Theim, K.R.; Ranzenhofer, L.; Tanofsky-Kraff, M.; Yanovski, J.A. Serum Brain-Derived Neurotrophic Factor Concentrations in Lean and Overweight Children and Adolescents. J. Clin. Endocrinol. Metab. 2006, 91, 3548-3552. [CrossRef]

51. Martin, A.; Booth, J.N.; Mcgeown, S.; Niven, A.; Sproule, J.; Saunders, D.H.; Reilly, J.J.; Martin, A. Longitudinal Associations Between Childhood Obesity and Academic Achievement: Systematic Review with Focus Group Data. Curr. Obes. Rep. 2017. [CrossRef]

52. Caird, J.; Kavanagh, J.; Mara-eves, O.; Oliver, K.; Oliver, S.; Stansfield, C.; Thomas, J. Does Being Overweight Impede Academic Attainment? A Systematic Review. Health Educ. J. 2014, 73, 497-521. [CrossRef]

53. Rodrigues, P.F.S.; Pandeirada, J.N.S.; Bem-haja, P. The Trait Anxiety Scale for Children: A Validation Study for European Portuguese Children and Adolescents. Eur. J. Dev. Psychol. 2017, 1-9. [CrossRef]

54. Beesdo, K.; Knappe, S.; Pine, D.S. Anxiety and Anxiety Disorders in Children and Adolescents: Developmental Issues and Implications for DSM-V. Psychiatr. Clin. N. Am. 2009, 32, 483-524. [CrossRef]

55. Owens, M.; Stevenson, J.; Hadwin, J.A.; Norgate, R. When Does Anxiety Help or Hinder Cognitive Test Performance? The Role of Working Memory Capacity. Br. J. Psychol. 2014, 105, 92-101. [CrossRef]

56. Öst, L.; Ollendick, T.H. Brief, Intensive and Concentrated Cognitive Behavioral Treatments for Anxiety Disorders in Children: A Systematic Review and Meta-Analysis. Behav. Res. Ther. 2017. [CrossRef]

57. Barker, M.M.; Beresford, B.; Bland, M.; Fraser, L.K. Prevalence and Incidence of Anxiety and Depression among Children, Adolescents, and Young Adults with Life-Limiting Conditions: A Systematic Review and Meta-Analysis. JAMA Pediatr. 2019, 173, 835-844. [CrossRef] [PubMed]

58. Aritzeta, A.; Soroa, G.; Balluerka, N.; Muela, A. Reducing Anxiety and Improving Academic Performance Through a Biofeedback Relaxation Training Program. Appl. Psychophysiol. Biofeedback 2017. [CrossRef] [PubMed]

59. WHO. Estrategia Mundial Sobre Régimen Alimentario, Actividad Física Y Salud. La Actividad Física En Los Jóvenes. Available online: https://www.who.int/dietphysicalactivity/factsheet_young_people/es/ (accessed on 27 February 2021). 
60. Scudder, M.R.; Federmeier, K.D.; Raine, L.B.; Direito, A.; Boyd, J.K.; Hillman, C.H. Brain and Cognition The Association between Aerobic Fitness and Language Processing in Children: Implications for Academic Achievement. Brain Cogn. 2014, 87, 140-152. [CrossRef]

61. Lonigan, C.J.; Burgess, S.R.; Anthony, J.L. Development of Emergent Literacy and Early Reading Skills in Preschool Children: Evidence From a Latent-Variable Longitudinal Study. Dev. Psychol. 2000, 36, 596-613. [CrossRef] [PubMed]

62. Moore, R.D.; Drollette, E.S.; Scudder, M.R.; Bharij, A.; Hillman, C.H. The Influence of Cardiorespiratory Fitness on Strategic, Behavioral, and Electrophysiological Indices of Arithmetic Cognition in Preadolescent Children. Front. Hum. Neurosci. 2014, 8 , 1-14. [CrossRef]

63. Pontifex, M.B.; Raine, L.B.; Johnson, C.R.; Chaddock, L.; Voss, M.W.; Cohen, N.J.; Kramer, A.F.; Hillman, C.H. Cardiorespiratory Fitness and the Flexible Modulation of Cognitive Control in Preadolescent Children. J. Cogn. Neurosci. 2011, 23, 1332-1345. [CrossRef]

64. Kramer, A.F.; Colcombe, S.; Erickson, K.; Belopolsky, A.; McAuley, E.; Cohen, N.J.; Webb, A.; Jerome, G.J.; Marquez, D.X.; Wszalek, T.M. Effects of Aerobic Fitness Training on Human Cortical Function: A Proposal. J. Mol. Neurosci. 2002, 19, 227-231. [CrossRef]

65. Chaddock, L.; Erickson, K.I.; Prakash, R.S.; Voss, M.W.; VanPatter, M.; Pontifex, M.B.; Hillman, C.H.; Kramer, A.F. A Functional MRI Investigation of the Association between Childhood Aerobic Fitness and Neurocognitive Control. Biol. Psychol. 2012, 89, 260-268. [CrossRef] [PubMed]

66. Thøgersen-Ntoumani, C.; Ntoumanis, N. The Role of Self-Determined Motivation in the Understanding of Exercise-Related Behaviours, Cognitions and Physical Self-Evaluations. J. Sports Sci. 2006, 24, 393-404. [CrossRef] [PubMed]

67. Erickson, K.I.; Voss, M.W.; Prakash, R.S.; Basak, C.; Szabo, A.; Chaddock, L.; Kim, J.S.; Heo, S.; Alves, H.; White, S.M.; et al. Exercise Training Increases Size of Hippocampus and Improves Memory. Proc. Natl. Acad. Sci. USA 2011, 108, $3017-3022$. [CrossRef]

68. Vaynman, S.; Ying, Z.; Gomez-Pinilla, F. Hippocampal BDNF Mediates the Efficacy of Exercise on Synaptic Plasticity and Cognition. Eur. J. Neurosci. 2004, 20, 2580-2590. [CrossRef]

69. Fleming, S.; Thompson, M.; Stevens, R.; Heneghan, C.; Plüddemann, A.; Maconochie, I.; Tarassenko, L.; Mant, D. Normal Ranges of Heart Rate and Respiratory Rate in Children from Birth to 18 Years of Age: A Systematic Review of Observational Studies. Lancet 2011, 377, 1011-1018. [CrossRef]

70. O'Leary, F.; Hayen, A.; Lockie, F.; Peat, J. Defining Normal Ranges and Centiles for Heart and Respiratory Rates in Infants and Children: A Cross- Sectional Study of Patients Attending an Australian Tertiary Hospital Paediatric Emergency Department. Arch. Dis. Child 2015, 100, 733-737. [CrossRef]

71. Silvetti, M.S.; Drago, F.; Ragonese, P. Heart Rate Variability in Healthy Children and Adolescents Is Partially Related to Age and Gender. Int. J. Cardiol. 2001, 81, 169-174. [CrossRef]

72. Clemente-Suárez, V.J.; Hormeño-Holgado, A.; Jiménez, M.; Benitez-Agudelo, J.C.; Navarro-Jiménez, E.; Perez-Palencia, N.; Maestre-Serrano, R.; Laborde-Cárdenas, C.C.; Tornero-Aguilera, J.F. Dynamics of Population Immunity Due to the Herd Effect in the COVID-19 Pandemic. Vaccines 2020, 8, 236. [CrossRef]

73. Campa, F.; Toselli, S.; Mazzilli, M.; Gobbo, L.A.; Coratella, G. Assessment of Body Composition in Athletes: A Narrative Review of Available Methods with Special Reference to Quantitative and Qualitative Bioimpedance Analysis. Nutrients 2021, 13, 1620. [CrossRef] 